\title{
KINERJA KELOMPOK USAHA BERSAMA (KUB) NELAYAN GILLNET DI BARSELA ACEH
}

\author{
Kinerja Kelompok Usaha Bersama (KUB) Nelayan Gillnet di Barsela Aceh
}

Oleh:

Muhammad Rizal1, Budy Wiryawan², Sugeng Hari Wisudo², Iin Solihin², John Haluan²

\author{
1 Jurusan Ilmu Perikanan, Fakultas Perikanan dan Ilmu Kelautan, Universitas Teuku Umar \\ 2 Departemen Pemanfaatan Sumberdaya Perikanan, Fakultas Perikanan dan Ilmu Kelautan, Institut Pertanian Bogor \\ * Korespondensi: rizalmuhammadfpikutu@gmail.com
}

Diterima: 26 April 2016; Disetujui: 18 November 2016

\begin{abstract}
Nowadays, the development of fisheries strategic issues is related to poverty and welfare of fishermen. In 2010 - 2014, Ministry of Marine and Fisheries implemented Business Development Program of Rural Area by creating a Joint Business Group (JBG) to help traditional and small scale fishermen who categorized as poor. This study aimed to determine the performance of JBG of gillnet fishermen and to identify the attributes of performance (aspects of institutional, sociocultural, economic, environmental and policy) in Barsela Aceh. Data was collected by purposive sampling method from 13 JBG of gillnet fishermen. IPA analysis and gap analysis were performed to measure each attribute and attribute's performance. The results showed that the value of the gap in the aspect of the institution of 1.87, and socio-cultural aspect of 1.91, which are categorized as good enough. Furthermore, the value of the economic aspect $(2,12)$, environmental aspect $(2,43)$ and policy aspect $(2.21)$ are categorized as less good. The attributes which categorized as a top priority (in quadrant $A$ ) are the aspect of institution, namely; human resources quality of JBG, the level of utilization of information technology and marketing, participation in training event, frequency of training held by related agencies and traditional institutions and the effectiveness of PPTK. Socio-cultural aspects are the desire to be independent culture, work ethic culture, group cohesiveness, and JBG assets are jointly managed. In economic aspect are active savings and loan activities, the level of turnover development of JBG and the level of market opportunities for JBG fishermen's business. Environmental aspects are the effectiveness of target fish species catch, high economic value of fish and environment-friendly technologies. Policy aspects are sanctioned policies for fictitious JBG, policies about who can become a member of JBG, policy management in preparing a joint business plan and sanctions for members who violate the rules.
\end{abstract}

Keywords: Barsela Aceh, JBG, gillnet fishermen

\section{ABSTRAK}

Perkembangan isu strategis perikanan saat ini adalah kemiskinan dan kesejahteraan nelayan. Kementerian Kelautan dan Perikanan Tahun 2010-2014 melaksanakan Program Pengembangan Usaha Mina Perdesaan (PUMP) dengan membuat Kelompok Usaha Bersama (KUB) untuk membantu nelayan tradisional dan kecil yang masih tergolong miskin. Penelitian ini bertujuan yaitu mengetahui kinerja KUB nelayan gillnet dan mengidentifikasi atribut kinerjanya (aspek lembaga, sosial budaya, ekonomi, lingkungan dan kebijakan) di Barsela Aceh. Metode pengambilan data purposive sampling, dimana data diambil secara sengaja pada $13 \mathrm{KUB}$ nelayan gillnet. Analisis data yang digunakan yaitu analisis IPA untuk menilai setiap atribut dan analisis kesenjangan (gap) untuk menilai kinerja setiap atribut. Hasil penelitian menunjukkan bahwa nilai 
kesenjangan pada aspek lembaga $(1,87)$ dan aspek sosial budaya $(1,91)$ yaitu katagori cukup baik. Selanjutnya nilai pada aspek ekonomi $(2,12)$, aspek lingkungan $(2,43)$ dan aspek kebijakan $(2,21)$ yaitu katagori kurang baik. Serta atribut yang prioritas yaitu posisi atribut kuadran A (diprioritaskan) pada aspek lembaga adalah kualitas SDM KUB, tingkat pemanfaatan akses informasi teknologi dan pemasaran, keikutsertaan kegiatan pelatihan, intensitas pembinaan dari instansi terkait dan lembaga adat dan keefektifan PPTK. Aspek sosial budaya adalah budaya ingin mandiri, budaya etos kerja, kekompakan kelompok, dan aset KUB dikelola secara bersama. Aspek ekonomi adalah aktifnya kegiatan simpan pinjam, tingkat perkembangan omset KUB dan tingkat peluang pasar untuk usaha KUB nelayan. Aspek lingkungan adalah efektivitas jenis ikan target yang tertangkap, ikan ekonomis tinggi dan teknologi ramah lingkungan. Aspek kebijakan adalah aturan sanksi bagi KUB fiktif, kebijakan tentang yang bisa menjadi anggota KUB, kebijakan manajemen dalam menyusun rencana usaha bersama dan aturan sanksi bagi anggota yang melanggar.

Kata kunci: Barsela Aceh, KUB, nelayan gillnet

\section{PENDAHULUAN}

Perkembangan isu strategis perikanan sekarang ini adalah kemiskinan dan kesejahteraan nelayan, dimana kondisi usaha perikanan tangkap di Indonesia pada saat ini menunjukan fakta bahwa masih rendahnya keberpihakan pada upaya peningkatan kesejahteraan nelayan. Kondisi ini mengakibatkan rendahnya tingkat pendapatan nelayan sebagai akibat dari rendahnya produktivitas dan efisiensi usaha, tingginya biaya produksi, keterbatasan biaya yang mengakibatkan fasilitas modern masih sulit dijangkau nelayan, rendahnya atau sulit akses terhadap permodalan, rendahnya keterampilan nelayan dan manajemen usaha, prasarana, teknologi dan belum optimalnya pasar.

Pemerintah pusat telah melakukan berbagai macam bantuan untuk disalurkan kepada nelayan, khususnya nelayan skala kecil $(<5 G T)$ di (barat selatan) Barsela aceh. Akan tetapi upaya ini belum dapat meningkatkan kesejahteraan nelayan. Stanford et al. (2014), mengemukakan bahwa tiga isu penting terkait peningkatkan kesejahteraan nelayan dalam pengentasan kemiskinan adalah bidang sosial, ekonomi dan di proyek pengembangan kesejahteraan. Namun menurut Dowling et al. (2014) menjelaskan bahwa dalam menuju kesejahteraan nelayan diperlukan data kemiskinan nelayan yang harus evaluasi secara detail dan komprehensif. Kemudian peningkatan kesejahteraan merupakan tantangan bagi negara berkembang menghadapi kemiskinan dan kurang lapangan kerja alternatif (Muallil et al. 2014). Oleh sebab itu, Kementerian Kelautan dan Perikanan Tahun 2010-2014 melaksanakan Program Pengembangan Usaha Mina Perdesaan (PUMP) dengan membuat Kelompok Usaha Bersama (KUB) yang dilatarbelakangi bahwa kondisi sosial ekonomi masyarakat pesisir pantai khususnya yang bermata pencaharian nelayan tradisional dan kecil masih tergolong miskin dengan ukuran kapal < 5 GT.

Pembinaan nelayan skala kecil yang tergabung dalam KUB telah berlangsung selama 4 tahun di Barsela Aceh, khususnya di daerah Kabupaten Aceh Barat, Aceh Jaya dan Nagan Raya. Namun KUB di daerah tersebut belum menunjukkan tingkat aktivitasnya terhadap pengembangan usaha KUB itu sendiri, terutama dalam hal aktivitas kinerja nelayan KUB. Kinerja KUB secara dominan kurang aktif dan efektif dalam memanfaakan semua fasilitas yang didapatkannya. Oleh karena itu, tujuan penelitian ini adalah: 1) mengidentifikasi nilai atribut kinerja (aspek lembaga, sosial budaya, ekonomi, lingkungan dan kebijakan) di Barsela Aceh; 2) mengetahui kinerja KUB nelayan gillnet di Barsela Aceh.

\section{METODE}

Penelitian ini dilaksanakan pada bulan April hingga Desember 2015. Wilayah kajian adalah di kabupaten yang berada di wilayah Barsela Aceh yang meliputi Kabupaten Aceh Barat, Aceh Jaya dan Naganraya.

Metode pengumpulan data dilakukan dengan menggunakan purposive sampling yaitu teknik pengumpulan sampel secara sengaja terhadap $13 \mathrm{KUB}$ gillnet dari total jumlah 13 KUB gillnet yang mendapatkan bantuan PUMP di Barsela Aceh. Ke-13 KUB tersebar di tiga kabupaten yaitu 4 KUB di Kabupaten Aceh Jaya, 5 Kabupaten Aceh Barat dan 4 KUB di Kabupaten Nagan Raya.

Data yang dikumpulkan dalam penelitian ini meliputi data primer dan sekunder. Data primer mengenai kinerja kelompok usaha bersama (KUB) nelayan gillnet di Barsela Aceh dilakukan dengan wawancara mendalam (indepth interview) dan focus group discussion terhadap 13 KUB nelayan gillnet yang ada di 
Barsela Aceh. Data sekunder dari KUB yang memperoleh bantuan langsung masyarakat (BLM) melalui program PUMP di Barsela Aceh diperoleh dari lembaga/instansi DKP Barsela Aceh. Jenis data yang digunakan pada Tabel 1 berikut ini.

Pengolahan data kinerja kelompok usaha bersama (KUB) nelayan gillnet di Barsela (Barat selatan) Aceh menggunakan metode Importance and Performance Analysis (IPA). Analisis ini dilakukan secara bertahap dan sistematis dengan mengetahui nilai kondisi eksisting dan kepentingan yang menjadi acuan dalam menggali isu strategis yang prioritas, pertahankan prestasi, prioritas rendah dan berlebihan. Perhitungan dalam analisis ini berasal dari isian kuesioner responden ahli. Pengolahan data dilakukan dilakukan dengan menggunakan program komputer Excel 2013 dengan menghasilkan gambar matriks kinerja KUB nelayan gillnet.

Selanjutnya data dianalisis dengan menggunakan analisis kesenjangan KUB dan Importance and Performance Analysis (IPA).

\section{Analisis kesenjangan KUB}

Penilaian terhadap kinerja KUB nelayan gillnet menggunakan analisis kesenjangan (gap Analysis) yaitu membandingkan antara persepsi nelayan terkait dengan tingkat kepentingan dan kondisi eksisting kinerja KUB. Semakin kecil kesenjangan (gap) antara skor tingkat kinerja dan skor tingkat kepentingan menurut responden, maka kinerja KUB nelayan gillnet semakin baik, demikian pula sebaliknya.

Menurut Santoso (2011), pengembangan pengukuran persepsi KUB nelayan terhadap nilai kinerja eksisting dan nilai tingkat kepentingan atau harapan untuk membantu mempermudah penilaian menggambarkan kriteria kinerja, dibuat selang frekuensi kelas untuk selisih nilai kinerja dan kepentingan. Penentuan skor tingkat kinerja dan kepentingan untuk menilai kesenjangan menggunakan skala 4 tingkat yaitu sangat baik (skor 1), cukup baik (skor 2), kurang baik (skor 3 ) dan buruk (skor 4). Selanjutnya, untuk mengetahui selang penilaian kinerja agar diketahui kriterianya dapat ditentukan berdasarkan Tabel 2.

\section{Analisis Importance and Performance Analysis (IPA)}

Selanjutnya atribut yang berpengaruh terhadap kinerja KUB dianalisis dengan menggunakan Importance and Performance Analysis (IPA). IPA adalah analisis yang dapat memberikan pentunjuk kepada setiap stakeholder tentang nilai atribut atau variabel yang dianggap penting dalam setiap kinerja KUB, tetapi masih kurang mendapatkan perhatian dari stakeholder sehingga kinerja menjadi kurang baik (Santoso 2011); (Firdausi et al. 2014). IPA menggambarkan kinerja (performance) KUB nelayan gillnet dengan melihat tingkat nilai kepentingan atau harapan dengan kondisi eksisting dalam bentuk grafik. Tipe grafik yang untuk IPA adalah XY (scatter) (Arifin 2007).

Penilaian tingkat kinerja KUB nelayan gillnet di Barsela Aceh merupakan hasil yang diperoleh pada saat melakukan pra penelitian yang disesuaikan dengan kondisi di lingkungan (letak geografis) dan modifikasi dari 5 dimensi kinerja tentang jasa (Rangkuti 2008). Adapun tahap-tahap analisis IPA dalam penentuan kinerja KUB nelayan gillnet di Barsela Aceh dapat dilihat pada Tabel 3.

Untuk mendapatkan informasi tentang tingkat kinerja KUB nelayan gillnet dilakukan dengan mengukur tingkat kepentingan dan tingkat kondisi eksisting kinerjanya. Diniah et al. (2012) menjelaskan skor tingkat kinerja eksisting dan tingkat kepentingan masing-masing informan keseluruhan faktor menggunakan rumus sebagai berikut:

$$
\mathrm{XI}=\frac{\sum X I}{n} \quad \mathrm{YI}=\frac{\sum Y I}{n}
$$

dengan:

\section{$\mathrm{XI}$ : Skor rata-rata tingkat kinerja atribut \\ $\mathrm{YI}$ : Skor rata-rata tingkat kepentingan terhadap atribut \\ $\mathrm{n}$ : Jumlah responden}

Diagram kartesius merupakan suatu matriks yang dibagi atas empat bagian yang dibatasi oleh dua garis yang berpotongan tegak lurus pada titik-titik (X dan Y) (Ramadhani et al. 2014). Diagram kartesius dibuat untuk memposisikan atribut sesuai dengan tingkat kepentingan dan tingkat kinerja eksisting berdasarkan hasil perhitungan nilai indeks kepentingan dan indeks kinerja eksisting KUB nelayan gillnet. Menurut Nugraha et al. (2014), pemetaan dilakukan untuk membagi setiap atribut dalam empat kuadran. Nilai rata-rata setiap atribut sebagai garis tengah pembagi pada sumbu $X$ (Kinerja eksisting) dan sumbu $Y$ (Kepentingan) (Gambar 1).

\section{Kuadran 1. Prioritas utama/ Concentrate Here}

Atribut yang terletak dalam kuadran ini merupakan atribut yang penting dan diharapkan oleh nelayan, tetapi persepsi dan kinerja aktual yang ada pada saat ini belum memuaskan. Atribut yang terletak pada kuadran ini juga merupakan prioritas untuk ditingkatkan. 
Tabel 1 Jenis data penelitian dan sumber data

\begin{tabular}{|c|c|c|c|}
\hline Jenis data & Sumber data & Metode pengambilan & Keterangan \\
\hline KUB Gillnet & $\begin{array}{l}\text { Data KUB di } \\
\text { DKP }\end{array}$ & Data sekunder & $\begin{array}{l}\text { KUB yang memperoleh BLM- } \\
\text { PUMP }\end{array}$ \\
\hline $\begin{array}{l}\text { Kinerja KUB } \\
\text { Nelayan }\end{array}$ & $\begin{array}{l}\text { Data primer di } \\
\text { KUB }\end{array}$ & $\begin{array}{l}\text { FDG secara in-depth } \\
\text { interview KUB }\end{array}$ & Kinerja KUB pada lima aspek \\
\hline
\end{tabular}

Tabel 2 Selang kinerja KUB nelayan gillnet di Barsela Aceh

\begin{tabular}{cc}
\hline Nilai Skor & Kriteria penilaian kinerja \\
\hline $0-1$ & Kinerja sangat baik \\
$1-2$ & Kinerja cukup baik \\
$2-3$ & Kinerja kurang Baik \\
$3-4$ & Kinerja buruk \\
\hline
\end{tabular}

Tabel 3 Aspek dan atribut kinerja KUB nelayan gillnet di Barsela Aceh

\begin{tabular}{|c|c|c|}
\hline Aspek & Atribut & Keterangan \\
\hline Lembaga & 16 & $\begin{array}{l}\text { Kriteria menjadi KUB, struktur organisasi, peraturan, evaluasi } \\
\text { lembagan dan efektivitasnya }\end{array}$ \\
\hline Sosial Budaya & 25 & $\begin{array}{l}\text { Pola pikir, hubungan KUB, partisipasi, etos kerja, komitmen, } \\
\text { menjaga kerukunan, budaya mandiri dan pengelolaan asset }\end{array}$ \\
\hline Ekonomi & 17 & $\begin{array}{l}\text { Tingkat pemanfaatan dan penguliran modal, efisiensi produksi, } \\
\text { minat menabung, membuat neraca keuangan, pola pembagian } \\
\text { hasil, LKM mandiri dan usaha mikro kreatif }\end{array}$ \\
\hline Lingkungan & 9 & $\begin{array}{l}\text { Efisiensi penangkapan, ikan ekonomi tinggi dan penangkapan } \\
\text { ramah lingkungan serta bertangqung jawab }\end{array}$ \\
\hline Kebijakan & 11 & $\begin{array}{l}\text { Tata aturan KUB, sanksi yang melanggar dan peraturan } \\
\text { pembagian laba }\end{array}$ \\
\hline
\end{tabular}

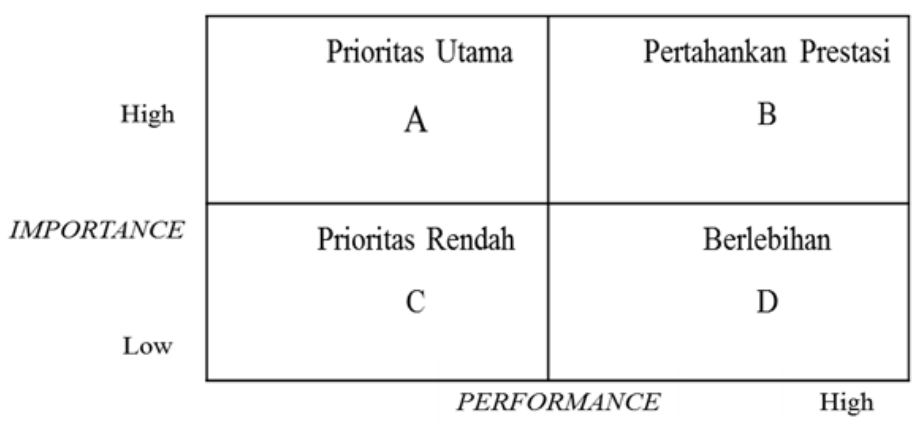

Gambar 1 Diagram importance/performance matriks (Rangkuti 2008)

Kuadran 2. Pertahankan prestasi/ Keep up with the good work)

Atribut yang terletak pada kuadran ini merupakan atribut yang penting dan diharapkan dan kinerjanya sudah memuaskan. Pihak manajemen berkewajiban memastikan bahwa kinerja institusi dapat terus mempertahankan prestasi yang telah dicapai.

\section{Kuadran 3. Prioritas rendah/ Low priority}

Atribut yang terletak pada kuadran ini mempunyai tingkat kinerja aktual yang rendah, sekaligus dianggap tidak terlalu penting oleh konsumen sehingga manajemen tidak perlu memprioritaskan pada faktor-faktor tersebut.

\section{Kuadran 4. Berlebihan/ Possibly Overkill)}

Faktor-faktor yang terletak pada kuadran ini dianggap sudah memuaskan kinerjanya akan tetapi tidak terlalu penting.

\section{HASIL}

\section{Analisis Nilai Kinerja Atribut KUB Nelayan Gillnet di Barsela Aceh}

Penilaian kinerja KUB menggunakan analisis kesenjangan (GAP) dan analisis IPA (Importance and Performance Analysis) dengan melihat 5 aspek yang meliputi aspek lembaga, sosial budaya, ekonomi, ekologi/lingkungan dan kebijakan. Analisis kesenjangan diperlukan untuk mengetahui tingkat nilai kinerja yang dibagi dalam 4 skala adalah baik, cukup baik, kurang baik dan buruk, berdasarkan kondisi eksisting dan tingkat kepentingan pada setiap aspek. Kemudian analisis IPA diperlukan untuk menentukan posisi kinerja pada masing-masing atribut atau variabel di dalam diagram yang dibagi menjadi 4 kuadran berdasarkan nilai skor kinerja. Adapun nilai kinerja KUB nelayan gillnet di Barsela Aceh sebagai berikut: 


\section{Aspek lembaga}

Berdasarkan hasil penilaian informan dari 16 atribut aspek lembaga KUB nelayan gillnet menyatakan bahwa tingkat kinerja KUB dalam pelaksanaan program PUMP (pengembangan usaha mina perdesaan) menurut nilai rata-rata kondisi eksisting 1,60, nilai penting atau harapan 3,46 dan nilai gap (kesenjangan) 1,87. Tingkat nilai kinerja aspek lembaga KUB nelayan di Barsela Aceh dapat dilihat pada Tabel 4.

Berdasarkan hasil penilaian tingkat kinerja eksisting $(\mathrm{X})$ dan tingkat kepentingan $(\mathrm{Y})$ pada Tabel 3 diketahui bahwa nilai kesenjangan (GAP) adalah 1,87. Nilai gap kinerja KUB nelayan gillnet di Barsela Aceh pada aspek lembaga termasuk dalam katagori kinerja cukup baik. Oleh karena itu, nilai kesenjangan pada aspek lembaga ini dapat dipertahankan dengan baik dan dapat meningkatkan kinerja KUB nelayan melalui program pemberdayaan nelayan yang kreatif dan produktif menuju pengentasan kemiskinan nelayan gillnet di Barsela Aceh.

Guna mempertajam analisis mengenai atribut-atribut yang berpengaruh terhadap kinerja KUB selanjutnya dilakukan analisis IPA (Importance and Performance Analysis). Analisis ini dilihat melalui diagram kartesius yang dilakukan dengan cara menghitung letak batas dua garis yang berpotongan tegak lurus $(X, Y)$. Garis tengah sumbu $X$ adalah 1,60 dan sumbu $Y$ adalah 3,46 yang merupakan nilai rata-rata tingkat kinerja eksisting dan tingkat kepentingan atau harapan. Posisi setiap atribut disajikan pada Gambar 2.

\section{Aspek sosial budaya}

Tingkat kinerja aspek sosial budaya KUB nelayan gillnet diketahui bahwa tingkat nilai rata-rata kondisi eksisting di lapang (kondisi saat ini) adalah 1,59 dan tingkat nilai kepentingan atau harapan adalah 3,50. Nilai kinerja KUB nelayan gillnet di Barsela Aceh dapat dilihat pada Tabel 5 .

Berdasarkan penilaian tingkat kinerja eksisting $(\mathrm{X})$ dan tingkat kepentingan $(\mathrm{Y})$ pada Tabel 3 diketahui nilai kesenjangan (GAP) adalah 1,91. Hal ini diperoleh berdasarkan penilaian aspek sosial budaya masuk katagori dalam kinerja cukup baik. Oleh karena itu, nilai kesenjangan pada aspek sosial budaya ini perlu diperhatikan atribut-atribut yang kinerjanya belum efektif.

Kemudian dalam menilai kinerja setiap atribut-atribut pada aspek sosial budaya digunakan analisis IPA. Penentuan setiap posisi dilakukan melalui garis tengah sumbu $X$ adalah 1,59 dan sumbu $Y$ adalah 3,50 yang merupakan nilai rata-rata tingkat kinerja eksisting dan tingkat kepentingan atau harapan. Posisi setiap atribut pada aspek sosial budaya disajikan pada Gambar 3.

\section{Aspek ekonomi}

Berdasarkan hasil penilaian informan terhadap 17 atribut yang ada dalam aspek ekonomi tentang kinerja KUB nelayan gillnet di Barsela Aceh, memiliki nilai rata-rata kinerja eksisting sebesar 1,41 dan nilai tingkat kepentingan 3,53. Oleh sebab itu, kondisi kinerja KUB nelayan gillnet dalam aspek ekonomi dapat diketahui dengan baik. Penilaian kinerja eksisting dan tingkat kepentingan pada aspek ekonomi dapat dilihat pada Tabel 6.

Nilai kesenjangan yang diperoleh pada aspek ekonomi adalah 2,12. Nilai gap ini berada pada kondisi kurang baik. Sehingga dibutuhkan komitmen semua stakeholder untuk lebih memperhatikan atribut-atribut kinerja yang belum efektif dalam upaya melakukan program pemberdayaan KUB nelayan gillnet menuju mandiri dan sejahtera.

Selanjutnya untuk mengetahui secara jelas penempatan atribut, maka digunakan analisis IPA. Penentuan posisi setiap atribut pada diagram cartesius yang dilakukan dengan menghitung letak batas dua garis yang berpotongan tegak lurus pada $(X, Y)$. Garis tengah sumbu $X$ adalah 1,41 dan sumbu $Y$ adalah 3,53 yang merupakan nilai rata-rata tingkat kinerja eksisting dan tingkat kepentingan atau harapan. Posisi setiap atribut disajikan pada Gambar 4.

\section{Aspek lingkungan}

Nilai kinerja aspek lingkungan KUB nelayan gillnet Barsela Aceh diperoleh nilai rata-rata kinerja eksisting 1,16 dan nilai tingkat kepentingan 3,59. Nilai kinerja KUB aspek lingkungan dapat dilihat pada Tabel 7.

Hasil analisis diketahui bahwa nilai kesenjangan KUB nelayan gillnet pada aspek lingkungan di Barsela Aceh adalah 2,43. Nilai yang diperoleh menunjukkan bahwa kinerja KUB nelayan gillnet selama ini berada dalam katagori kinerja kurang baik. Oleh karena itu, hasil penilaian ini menunjukkan bahwa kondisi kinerja KUB nelayan gillnet kurang efektif dalam aspek lingkungan.

Pada Gambar 5 disajikan posisi setiap atribut dalam diagram cartesius yang dihitung melalui batas dua garis yang berpotongan tegak lurus pada sumbu $(X, Y)$. Garis tengah 
sumbu $X$ merupakan nilai rata-rata tingkat kinerja eksisting, yaitu 1,16 dan garis sumbu $Y$ merupakan nilai rata-rata tingkat kepentingan 3,59 .

\section{Aspek Kebijakan}

Berdasarkan penilaian informan terhadap 11 atribut pada aspek kebijakan, maka hasil nilai rata-rata tingkat kondisi eksisting adalah $1,48(37,06 \%)$ dan nilai penting atau harapan adalah 3,69 (92,31\%) dengan nilai kesenjangan $2,21(55,25 \%)$. Nilai tingkat kinerja eksisting (X) dan nilai kepentingan (Y) pada aspek kebijakan dapat dilihat pada Tabel 8.

Setelah diperoleh nilai kinerja kondisi eksisting dan tingkat kepentingan pada aspek kebijakan KUB nelayan gillnet di Barsela Aceh, maka dapat diketahui nilai kesenjangan pada aspek tersebut yaitu 2,21. Nilai ini berada pada kategori /skala kurang baik.

Selanjutnya untuk menempatkan atributatribut pada aspek kebijakan, digunakan analisis IPA. Berdasarkan hasil penentuan posisi setiap atribut pada aspek kebijakan dapat dilihat bahwa garis yang membatasi kuadran adalah garis $X=1,48$ yang merupakan rata-rata skor tingkat kinerja eksisting dan garis $\mathrm{Y}=3,69$ yang merupakan rata-rata skor tingkat kepentingan. Posisi setiap atribut pada aspek kebijakan disajikan pada Gambar 6.

\section{PEMBAHASAN}

Nilai kesenjangan merupakan nilai yang memberikan informasi mengenai seberapa besar atribut-atribut tersebut telah memenuhi harapan nelayan. Menurut Pohandry et al. (2013), dijelaskan bahwa untuk mengetahui tingkat kepuasan secara keseluruhan dapat dilakukan dengan memperhatikan tingkat kepentingan dari atribut-atribut kinerja. Semakin besar gap suatu atribut maka tingkat kinerja nelayan semakin buruk dan sebaliknya. Kemudian, jika harapan lebih besar dari nilai kerjanya maka dikatakan KUB nelayan gillnet kecewa atau tidak puas terhadap atribut tersebut (Firdausi et al. 2014). Kondisi atribut berdasarkan analisis kesenjangan (gap) KUB nelayan gillnet di Barsela Aceh meliputi aspek lembaga $(1,87)$ dan aspek sosial budaya $(1,91)$ yang kinerjanya berada pada kategori cukup baik. Hal ini karena 16 atribut yang berada pada aspek lembaga dan 25 atribut pada aspek sosial budaya dalam pelakasanaan aktivitas kinerjanya ada kesesuaian antara nilai kinerja eksisting KUB nelayan dengan nilai tingkat kepentingan yang KUB nelayan harapkan. Sedangkan nilai kesenjangan (gap) pada aspek ekonomi $(2,12)$, aspek lingkungan $(2,43)$ dan aspek kebijakan $(2,21)$ berada pada skala nilai kurang baik. Kondisi kesenjangan pada aspek ini perlu diperhatikan oleh semua stakeholder untuk lebih meningkatkan kinerjanya. Apabila KUB nelayan tidak memperbaiki kinerja atribut tersebut dan membiarkan kinerjanya semakin buruk, maka dikhawatirkan KUB nelayan gillnet tetap dalam kondisi kehidupan memprihatikan (miskin) (Kohar et al. 2011). Kondisi ini akan memiliki pengaruh yang besar dalam aktivitas KUB nelayan gillnet menuju tingkat kemandirian dan kesejahteraan.

Analisis Importance and Performance Analysis (IPA) merupakan analisis yang melihat tingkat kesesuaian perbandingan antara skor tingkat kinerja (performance) dengan skor tingkat kepentingan (importance) yang akan menentukan posisi urutan prioritas peningkatan kinerja setiap atribut dalam variabel kualitas produk. Menurut Roslinawati (2013) menjelaskan bahwa persepsi masyarakat mengenai kepuasan dan motivasi dalam mengikuti Program Pemberdayaan nelayan adalah ingin memperoleh modal usaha dan membantu meningkatkan pendapatan rumah tangga. Hal ini merupakan pola pikir yang keliru terhadap bantuan yang diberikan oleh pemerintah sehingga berpengaruh terhadap kinerja nelayan. Posisi atribut yang sesuai berdasarkan tingkat kinerja dan tingkat kepentingan dapat dilihat pada kuadran berikut ini:

\section{Kuadran A (Prioritas utama)}

Pada diagram Cartesius, kinerja KUB nelayan gillnet di Barsela Aceh pada aspek lembaga, sosial budaya, ekonomi, lingkungan dan kebijakan sangat menyebar di setiap kuadran. Atribut yang terletak dalam kuadran ini merupakan atribut yang penting dan diharapkan oleh KUB nelayan. Akan tetapi persepsi dan kinerja aktual atau kondisi eksisting yang ada pada saat ini belum memuaskan. Atribut-atribut yang termasuk pada kuadran ini penanganannya perlu diprioritaskan dan ditingkatkan, karena jika tidak dapat mengurangi kinerja KUB nelayan gillnet. Menurut Nasir et al. (2012), atribut di kuadran A tersebut menjadi prioritas, dengan demikian setiap stakeholder harus dapat berkonsentrasi pada atribut-atribut tersebut demi tercapainya kepuasan nelayan, sehingga nelayan dapat lebih meningkatkan kinerjanya.

Hasil penelitian menunjukkan jumlah atribut pada aspek lembaga yang termasuk dalam kuadran $A$ ini adalah kualitas sumber daya manusia KUB (7); tingkat pemanfaatan akses informasi teknologi dan pemasaran (9); keikutsertaan dalam kegiatan pelatihan (12); 
Tabel 4 Penilaian tingkat kinerja keragaan $(X)$ dan tingkat kepentingan $(Y)$ pada aspek lembaga di KUB nelayan gillnet 2016

\begin{tabular}{|c|c|c|c|c|}
\hline No & Indikator & $\begin{array}{l}\text { Kondisi } \\
\text { Exsisting }\end{array}$ & $\begin{array}{c}\text { Nilai } \\
\text { Penting }\end{array}$ & Kesenjangan \\
\hline 1 & Pola pikir pengembangan usaha & 2,15 & 3,38 & 30,77 \\
\hline 2 & Tingkat kebersamaan yang baik dalam kelompok & 0,62 & 3,38 & 69,24 \\
\hline 3 & Partisipasi anggota KUB dalam mengikuti setiap program penyuluhan & 2,15 & 3,08 & 23,07 \\
\hline 4 & Persepsi anggota terhadap tugas pokok KUB & 1,85 & 3,38 & 38,47 \\
\hline 5 & dipilih menjadi pengurus dalam KUB & 2,46 & 3,08 & 15,38 \\
\hline 6 & Pola hubungan kelompok dengan individu usaha KUB & 1,85 & 3,69 & 46,16 \\
\hline 7 & Budaya ingin mandiri & 1,23 & 4,00 & 69,23 \\
\hline 8 & Menghadiri setiap rapat KUB & 2,15 & 3,38 & 30,77 \\
\hline 9 & Tingkat partisipasi keinginan menabung & 1,23 & 3,08 & 46,15 \\
\hline 10 & Budaya etos kerja & 1,23 & 4,00 & 69,23 \\
\hline 11 & prilaku anggota terhadap BLT dari pemerintah & 1,54 & 3,69 & 53,85 \\
\hline 12 & Memiliki tujuan yang sama dalam peningkatan pendapatan anggota & 1,23 & 3,38 & 53,85 \\
\hline 13 & Proses perencanaan, evaluasi dan monitoring kerja secara bersama & 1,85 & 3,38 & 38,47 \\
\hline 14 & Peningkatan pendapatan KUB setiap bulan/tahun & 1,23 & 3,38 & 53,85 \\
\hline 15 & Komitmen anggota untuk meningkatkan kreatifitas KUB & 1,54 & 3,69 & 53,85 \\
\hline 16 & Keterlibatan anggota KUB dalam RUB, & 2,15 & 4,00 & 46,15 \\
\hline 17 & penyelesaian konflik anggota KUB secara adat & 2,15 & 3,69 & 38,46 \\
\hline 18 & Teknih pengambilan keputusan secara bermusyawarah & 1,23 & 3,38 & 53,85 \\
\hline 19 & Memelihara kerukunan antar anggota & 0,92 & 3,38 & 61,54 \\
\hline 20 & Melakukan pencacatan pembukuan setiap kegiatan yang lengkap & 1,85 & 3,08 & 30,77 \\
\hline 21 & Koordinasi dan kekompakan kelompok, & 1,23 & 3,69 & 61,54 \\
\hline 22 & Menjaga nama baik KUB & 2,46 & 3,69 & 30,77 \\
\hline 23 & budaya usaha simpan pinjam KUB & 1,23 & 3,38 & 53,85 \\
\hline 24 & Asset KUB dikelola secara bersama-sama, & 0,92 & 4,00 & 76,92 \\
\hline \multirow[t]{3}{*}{25} & sifat Kepedulian dalam menjaga kelestarian lingkungan. & 1,23 & 3,08 & 46,15 \\
\hline & Jumlah & 39,69 & 87,38 & 47,69 \\
\hline & Rata-rata & 1,59 & 3,50 & 1,91 \\
\hline
\end{tabular}

Tabel 5 Penilaian tingkat kinerja keragaan $(\mathrm{X})$ dan tingkat kepentingan $(\mathrm{Y})$ pada aspek sosial budaya di KUB nelayan gillnet 2016

\begin{tabular}{|r|c|c|c|c|}
\hline No & Parameter & $\begin{array}{c}\text { Kondisi } \\
\text { Exsisting }\end{array}$ & Nilai Penting & Kesenjangan \\
\hline 1 & Kriteria dasar pemilihan anggota KUB & 1,54 & 3,38 & 1,85 \\
\hline 2 & Penyusunan Anggaran dasar dan anggaran rumah tangga & 2,46 & 3,69 & 1,23 \\
\hline 3 & Struktur organisasi dan ketertiban organisasi & 2,15 & 3,08 & 0,92 \\
\hline 4 & Mentaati semua aturan dalam AD/ART KUB & 1,54 & 3,38 & 1,85 \\
\hline 5 & Status perkembangan usaha anggota KUB & 2,46 & 3,08 & 0,62 \\
\hline 6 & Pengembangan kader KUB setiap tahun & 2,46 & 2,77 & 0,31 \\
\hline 7 & Kualitas sumber daya manusia KUB & 0,92 & 4,00 & 3,08 \\
\hline 8 & Tata aturan kepemilikan asset yang digunakan oleh KUB & 1,85 & 4,00 & 2,15 \\
\hline 9 & Tingkat pemanfaatan akses informasi teknologi dan pemasaran & 0,62 & 3,69 & 3,08 \\
\hline 10 & Menyusun, mengajukan, melaksanakan RUB sesuai panduan & 2,46 & 3,38 & 0,92 \\
\hline 11 & Evaluasi pelaksanaan rencana kerja & 1,23 & 3,08 & 1,85 \\
\hline 12 & Keikutsertaan dalam kegiatan pelatihan & 0,92 & 3,69 & 2,77 \\
\hline 13 & Intensitas pembinaan dari intansi terkait dan lembaga adat & 0,92 & 3,69 & 2,77 \\
\hline 14 & Proses perencanaan kerja setiap KUB & 1,23 & 3,38 & 2,15 \\
\hline 15 & Penyuluhan secara continue, & 2,15 & 3,38 & 1,23 \\
\hline 16 & Keefektifan PPTK (pegawai penyuluh tenaga kontrak) & 0,62 & 3,69 & 3,08 \\
\hline & Jumlah & 25,54 & 55,38 & 29,85 \\
\hline & Rata-rata & $\mathbf{1 , 6 0}$ & $\mathbf{3 , 4 6}$ & $\mathbf{1 , 8 7}$ \\
\hline
\end{tabular}


Tabel 6 Penilaian tingkat kinerja keragaan $(\mathrm{X})$ dan tingkat kepentingan $(\mathrm{Y})$ pada aspek ekonomi di KUB nelayan gillnet 2016

\begin{tabular}{|c|c|c|c|c|}
\hline No & Indikator & $\begin{array}{c}\text { Kondisi } \\
\text { Exs isting }\end{array}$ & $\begin{array}{c}\text { Nilai } \\
\text { Penting }\end{array}$ & Kes enjangan \\
\hline 1 & Tingkat pemanfaatan modal setiap KUB & 1,54 & 3,38 & 1,85 \\
\hline 2 & Kelancaran penguliran modal ke setiap anggota & 1,54 & 3,69 & 2,15 \\
\hline 3 & Efisiensi produksi usaha yang continue & 2,15 & 3,69 & 1,54 \\
\hline 4 & Tingkat persentase menabung dari keuntungan & 1,54 & 3,38 & 1,85 \\
\hline 5 & Minat tabungan anggota KUB & 1,85 & 3,38 & 1,54 \\
\hline 6 & Aktifinya kegiatan simpan pinjam anggota KUB & 1,23 & 3,69 & 2,46 \\
\hline 7 & Tingkat perkembangan omset KUB & 0,62 & 4,00 & 3,38 \\
\hline 8 & Kinerja tingkat kerapian dan kecermatan pembukuan & 2,15 & 3,69 & 1,54 \\
\hline 9 & Pembukuan keuangan dan inventaris & 0,92 & 3,08 & 2,15 \\
\hline 10 & Tingkat peluang pasar untuk usaha KUB nelayan & 0,62 & 4,00 & 3,38 \\
\hline 11 & Tingkat komitmen dalam penyusunan rancangan keuangan & 2,15 & 3,38 & 1,23 \\
\hline 12 & Pengurus dan anggota KUB melakukan audit keuangan KUB & 1,54 & 3,38 & 1,85 \\
\hline 13 & Membuat laporan neraca keuangan akhir tahun & 1,23 & 3,08 & 1,85 \\
\hline 14 & Memberdayakan kebiasaan menabung untuk kebutuhan ekonomi yang akan datang & 1,23 & 3,38 & 2,15 \\
\hline 15 & Pola pembagian hasil antar anggota & 0,62 & 3,08 & 2,46 \\
\hline 16 & Terwujudnya LKM yang mandiri & 1,54 & 4,00 & 2,46 \\
\hline \multirow[t]{3}{*}{17} & Pengembangan usaha kearah ekonomi usaha produktif & 1,54 & 3,69 & 2,15 \\
\hline & Jumlah & 24,00 & 60,00 & 36,00 \\
\hline & Rata-rata & 1,41 & 3,53 & 2,12 \\
\hline
\end{tabular}

Tabel 7 Penilaian tingkat kinerja keragaan $(\mathrm{X})$ dan tingkat kepentingan $(\mathrm{Y})$ pada aspek lingkungan di KUB nelayan gillnet 2016

\begin{tabular}{|c|c|c|c|c|}
\hline No & Indikator & Kondisi Exsisting & $\begin{array}{c}\text { Nilai } \\
\text { Penting }\end{array}$ & Kesenjangan \\
\hline 1 & Status terjaga wilayah perairan lingkungan dari pencemaran & 1,85 & 3,69 & 1,85 \\
\hline 2 & Tingkat efektivitas penangkapan ikan & 1,23 & 3,69 & 2,46 \\
\hline 3 & Jenis ikan layak tangkap di perairan & 0,92 & 3,38 & 2,46 \\
\hline 4 & efektivitas jenis ikan target yang tertangkap & 0,62 & 4,00 & 3,38 \\
\hline 5 & ikan ekonomis tinggi & 0,62 & 3,69 & 3,08 \\
\hline 6 & keadaan lingkungan fishing ground & 1,54 & 3,08 & 1,54 \\
\hline 7 & Musim penangkapan ikan; & 1,85 & 3,38 & 1,54 \\
\hline 8 & Keberlanjutan sumberdaya ikan & 1,23 & 3,38 & 2,15 \\
\hline \multirow[t]{3}{*}{9} & Teknologi ramah lingkungan & 0,62 & 4,00 & 3,38 \\
\hline & Jumlah & 10,46 & 32,31 & 21,85 \\
\hline & Rata-rata & 1,16 & 3,59 & 2,43 \\
\hline
\end{tabular}

Tabel 8 Penilaian tingkat kinerja keragaan (X) dan tingkat kepentingan ( $\mathrm{Y}$ ) pada aspek kebijakan di KUB nelayan gillnet 2016

\begin{tabular}{|c|c|r|r|r|}
\hline No & Indikator & $\begin{array}{c}\text { Kondisi } \\
\text { Exsisting }\end{array}$ & $\begin{array}{c}\text { Nilai } \\
\text { Penting }\end{array}$ & Kesenjangan \\
\hline 1 & Peraturan tata cara menjadi anggota KUB & 1,54 & 4,00 & 2,46 \\
\hline 2 & Aturan dasar dalam pemilihan jenis usaha & 1,85 & 3,69 & 1,85 \\
\hline 3 & Aturan tentang pemilihan ketua dan pengurus KUB & 2,46 & 3,38 & 0,92 \\
\hline 4 & aturan sanksi bagi KUB fiktif & 0,62 & 4,00 & 3,38 \\
\hline 5 & Kebijakan tentang nelayan yang bisa menjadi anggota KUB & 0,62 & 3,69 & 3,08 \\
\hline 6 & peraturan mendirikan dan rekrut anggota KUB & 2,15 & 4,00 & 1,85 \\
\hline 7 & Peraturan dalam mengelola keuangan & 1,54 & 3,38 & 1,85 \\
\hline 8 & Kebijakan manajemen dalam menyusun rencana usaha bersama & 1,23 & 3,69 & 2,46 \\
\hline 9 & Tata cara simpan pinjam uang oleh anggota KUB & 2,15 & 3,38 & 1,23 \\
\hline 10 & Aturan sanksi bagi anggota KUB yang melanggar & 0,62 & 4,00 & 3,38 \\
\hline 11 & Peraturan tentang pembagian hasil laba antar anggota KUB & 1,54 & 3,38 & 1,85 \\
\hline & Jumlah & 16,31 & 40,62 & 24,31 \\
\hline & Rata-rata & 1,48 & 3,69 & 2,21 \\
\hline
\end{tabular}




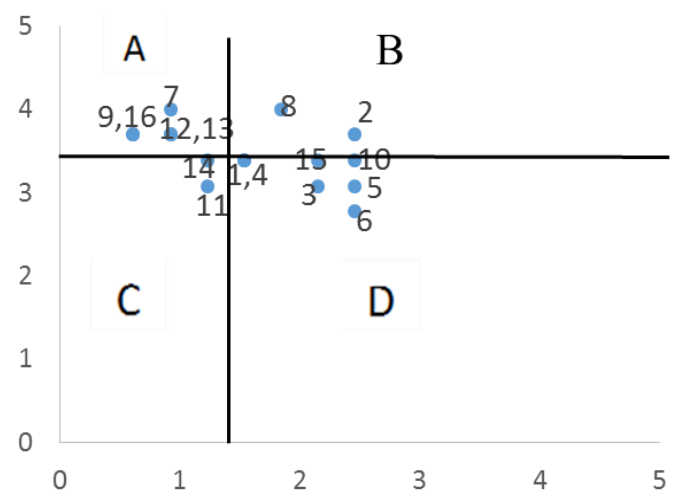

Gambar 2 Diagram Cartesius IPA aspek lembaga KUB nelayan gillnet di Barsela Aceh 2016

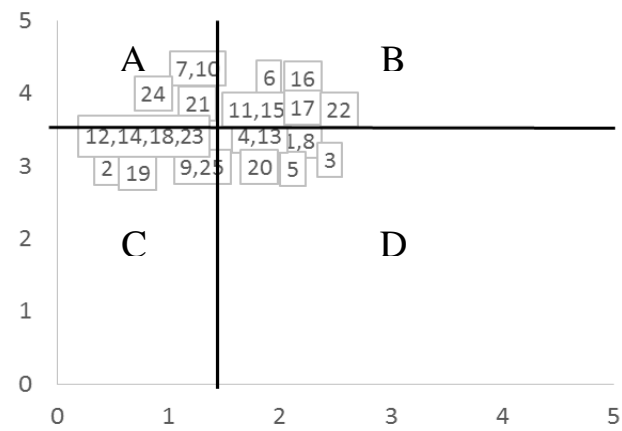

Gambar 3 Diagram Cartesius IPA aspek sosial budaya KUB nelayan gillnet di Barsela Aceh 2016

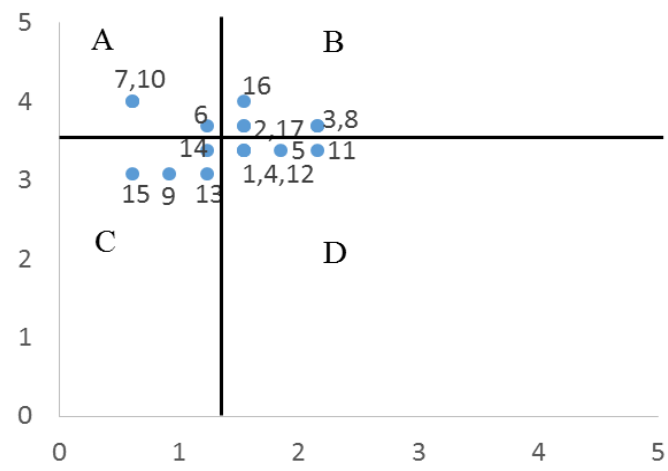

Gambar 4 Diagram Cartesius IPA aspek ekonomi KUB nelayan gillnet di Barsela Aceh 2016

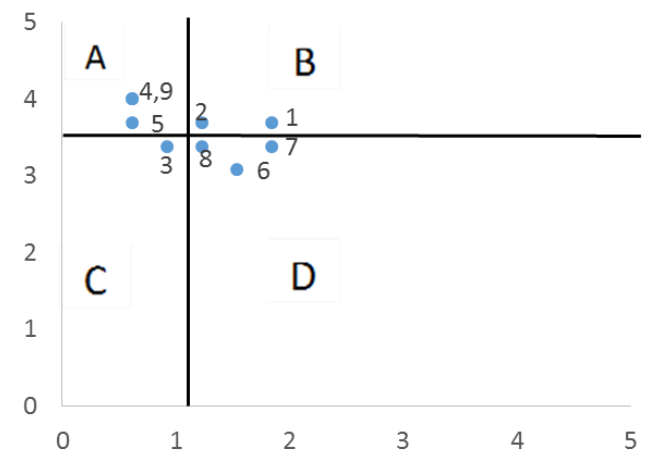

Gambar 5 Diagram Cartesius IPA aspek lingkungan KUB nelayan gillnet di Barsela Aceh 2016 


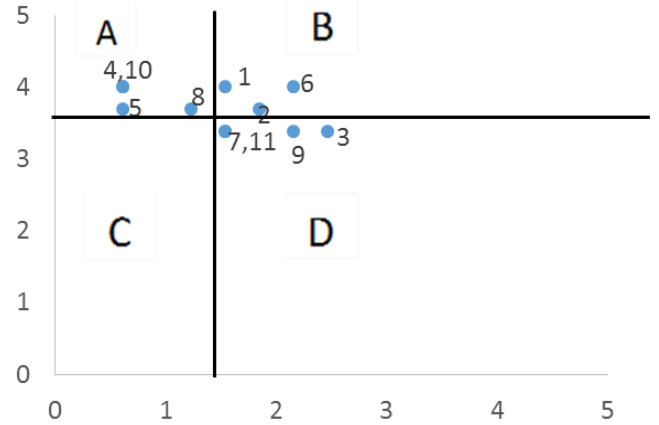

Gambar 6 Diagram Cartesius IPA aspek kebijakan KUB nelayan di Barsela Aceh 2016

intensitas pembinaan dari intansi terkait dan lembaga adat (13); dan keefektifan PPTK (pegawai penyuluh tenaga kontrak) (16). Menurut hasil FGD (focus group discussion), menunjukkan bahwa sebagian besar sumber daya manusia KUB nelayan gillnet masih rendah, sehingga menyebabkan sulit beradaptasi dengan perubahan zaman ke arah teknologi. Prinsip sebagian nelayan masih berpendapat bahwa, apa yang mereka lakukan sudah baik sehingga sulit untuk membuka dirinya dalam tingkat pemanfaatan teknologi dan informasi pemasaran, ikut serta pelatihan dan menerima pendapat orang lain. Menurut Lindawati et al. (2014), menurunnya tingkat kesejahteraan nelayan disebabkan oleh kurangnya kualitas masyarakat perikanan dan kelautan dalam hal akses modal, pasar dan teknologi termasuk kelompok usaha. Kemudian, rendahnya kinerja KUB nelayan tidak hanya terbatas kepada kurangnya keuangan, melainkan kurang kreatif, etos kerja, inovatif, kesempatan untuk bersosialisasi dengan berbagai potensi dan sumber daya yang dimiliki. Namun secara khusus, masalah ini lebih disebabkan karena lemah dan tertutupnya pengembangan potensi diri (Firdaus et al. 2013).

Berdasarkan informasi yang diperoleh, PPTK yang tugasnya sebagai pendamping KUB, hanya satu orang yang bekerja dalam menangani satu kabupaten. Sebagian besar PPTK yang ada di daerah Barsela Aceh tidak sesuai dengan bidang yang dibutuhkan oleh para nelayan. Selain itu, setiap PPTK tidak tinggal di lokasi pembinaan.

Atribut yang termasuk dalam kuadran A pada aspek sosial budaya meliputi: budaya ingin mandiri (7); budaya etos kerja (10); kekompakkan kelompok (21); dan aset KUB dikelola secara bersama-sama (24) dan harus segera ditingkatkan kinerjanya. Kuadran ini pada aspek sosial budaya sangat penting. Hal ini untuk dapat merubah pola pikir KUB nelayan ke arah yang memiliki semangat kerja yang tinggi (etos kerja) dan kebersamaan yang baik. Sehingga setiap program kerja yang ingin dicapai oleh setiap KUB nelayan dapat terealisasi dengan baik dan tepat.

Kemudian atribut yang termasuk pada aspek ekonomi di kuadran A (prioritas utama) ini adalah aktifnya kegiatan simpan pinjam anggota KUB (6); tingkat perkembangan omset KUB (7); tingkat peluang pasar untuk usaha KUB nelayan (10). Atribut yang ada pada aspek ekonomi ini perlu ditingkatkan kinerjanya. Oleh sebab itu, diperlukan keseriusan semua stakeholder yang terlibat untuk memprioritaskan program simpan pinjam anggota KUB yang efektif. Program simpan pinjam dibeberapa KUB tidak berjalan dengan baik. Sehingga para anggota KUB tidak saling percaya dengan sesama anggotanya dan mengetahui tingkat perkembangan omset KUB. Program berikutnya yang harus ditingkatkan kinerjanya adalah peluang pasar untuk menampung setiap hasil tangkapan KUB nelayan gillnet. Selama ini yang terjadi di lapang menunjukkan para KUB nelayan masih sulit menjual hasil tangkapanya dan tidak ada kepastian harga. Kondisi ini mengakibatkan KUB nelayan terpaksa menjual hasil tangkapan dengan harga murah dan jika tidak terjual maka hasil tangkapannya diolah menjadi ikan asin.

Penentuan posisi jumlah atribut pada aspek lingkungan di kuadran A (prioritas utama) adalah: efektivitas jenis ikan target yang tertangkap (4); ikan ekonomis tinggi (5); dan teknologi ramah lingkungan (9). Atribut pada kuadran ini sangat berpengaruh terhadap keberlanjutan sumber daya ikan di perairan. Oleh sebab itu, hal yang terpenting dan perlu ditingkatkan prioritasnya adalah selektif dalam menangkap ikan target. Sehingga diharapkan hasil tangkapan memiliki nilai jual tinggi. Selain itu perlu pula memperhatikan teknologi alat penangkapan yang digunakan (ramah lingkungan atau tidak), sehingga aman bagi 
nelayan dan sumber daya ikan. Adapun posisi atribut pada aspek kebijakan di kuadran A (prioritas utama) meliputi: aturan sanksi bagi KUB fiktif (4); kebijakan tentang nelayan yang bisa menjadi anggota KUB (5); kebijakan manajemen dalam menyusun rencana usaha bersama (8); aturan sanksi bagi anggota KUB yang melanggar (10). Setiap kebijakan yang ada pada kuadran ini penting untuk diprioritaskan dan ditingkatkan kinerjanya karena akan dapat berdampak pada efektivitas kinerja KUB nelayan gillnet dan kesejahteraan nelayan. Hal ini menyebabkan bahwa atribut pada kuadran $A$ ini dianggap belum bisa memenuhi tingkat kinerja yang baik terhadap keberlangsungan KUB nelayan gillnet. Oleh karena itu, atribut ini sangat perlu diprioritaskan dan ditingkatkan untuk diperbaiki dengan cara melakukan kegiatan perbaikan secara berkelanjutan dengan melibatkan semua stakeholder.

\section{Kuadran B (Pertahankan prestasi)}

Berdasarkan penentuan posisi hasil FGD (focus group discussion), diketahui jumlah atribut yang terletak pada kuadran ini merupakan atribut yang penting dan diharapkan serta kinerjanya sudah memuaskan. Atribut yang termasuk pada aspek lembaga pada kuadran II (pertahankan prestasi) meliputi: Penyusunan Anggaran dasar dan anggaran rumah tangga (2); dan Tata aturan kepemilikan asset yang digunakan oleh KUB (8). Atribut pada aspek lembaga ini sudah bagus untuk setiap KUB nelayan dalam melakukan penyusunan AD/ART KUB dan kepemilikan asset yang didampingi oleh petugas dari Dinas Kelautan dan Perikanan kabupaten di Barsela Aceh. Sedangkan atribut yang ada pada aspek sosial budaya dalam kuadran ini adalah pola hubungan kelompok dengan individu usaha KUB (6); persepsi anggota terhadap BLT dari pemerintah (11); peningkatan pendapatan KUB setiap bulan/tahun (15); keterlibatan anggota KUB dalam RUB (16); penyelesaian konflik anggota KUB secara adat (17); dan menjaga nama baik KUB (22). Kinerja yang sudah dicapai dengan baik pada atribut ini perlu tetap dipertahankan prestasinya sehingga setiap program kerja pada kuadran B dapat dilaksanakan dengan efektif.

Jumlah atribut atau variabel yang termasuk pada aspek ekonomi dalam aspek ekonomi adalah kelancaran penguliran modal ke setiap anggota (2); efisiensi produksi usaha yang berkelanjutan (3); kinerja tingkat kerapian dan kecermatan pembukuan (8); terwujudnya LKM yang mandiri (16); pengembangan usaha ke arah ekonomi usaha produktif (17). Atribut yang berada pada kuadran ini sudah memiliki kinerja yang baik sesuai dengan kapasitas dan kemampuan KUB nelayan. Tercermin dari adanya lembaga kewirausahaan mandiri (LKM) yang aktif dalam menjalankan kelompok usahanya menuju ke arah ekonomi usaha produktif secara berkelanjutan. Begitu juga atribut yang termasuk dalam aspek lingkungan meliputi: status terjaga wilayah perairan lingkungan dari pencemaran (1); dan tingkat efektivitas penangkapan ikan (2). Atribut yang ada pada aspek lingkungan ini sudah sangat bagus kinerjanya, dimana KUB nelayan gillnet dalam melakukan aktivitas penangkapan ikan tetap menjaga kondisi lingkungan. Sedangkan atribut peraturan tata cara menjadi anggota KUB (1); aturan dasar dalam pemilihan jenis usaha (2); dan peraturan mendirikan dan rekrut anggota KUB (6) berada pada aspek kebijakan. Efektivitas atribut tersebut sudah sangat bagus dijalankan oleh KUB nelayan gillnet di kawasan Barsela Aceh. Setiap anggota KUB sudah memahami aturan dasar mendapatkan BLT (bantuan langsung tunai) dari pemerintah dalam membantu produktivitas KUB. Kondisi seperti ini harus dipertahankan dengan baik sehingga atribut kinerja pada kuadran II tersebut dapat dikatakan sudah berhasil pelaksanaannya serta menjadi kekuatan setiap stakeholder dan KUB nelayan untuk mempertahankan prestasi kinerjanya.

\section{Kuadran C (Prioritas rendah)}

Atribut yang terletak pada kuadran ini mempunyai tingkat kinerja aktual yang rendah, sekaligus dianggap tidak terlalu penting oleh KUB nelayan gillnet di Barsela Aceh. Oleh karena itu pihak stakeholder belum perlu memprioritaskan atribut tersebut atau dengan kata lain atribut ini memiliki tingkat kinerja yang tidak terlalu istimewa. Atribut-atribut pada kuadran C (prioritas rendah) yang termasuk pada aspek lembaga adalah evaluasi pelaksanaan rencana kerja (11); dan proses perencanaan kerja setiap KUB (14). Atribut ini diabaikan oleh KUB nelayan karena dianggap tidak mempengaruhi aktivitas kinerja nelayan. Sedangkan atribut pada aspek sosial budaya meliputi: tingkat kebersamaan yang baik dalam kelompok (2); tingkat partisipasi keinginan menabung (9); memiliki tujuan yang sama dalam peningkatan pendapatan anggota (12); peningkatan pendapatan KUB setiap bulan/ tahun (14); teknik pengambilan keputusan secara bermusyawarah (18); memelihara kerukunan antar anggota (19); budaya usaha simpan pinjam KUB (23); dan sifat kepedulian dalam menjaga kelestarian lingkungan (25). Atribut pada kuadran ini juga dianggap oleh KUB nelayan tidak penting sehingga aktivitas kinerja para anggota KUB rendah atau buruk. 
Jumlah atribut yang termasuk dalam aspek ekonomi yang memiliki tingkat kinerja rendah pada kuadran $\mathrm{C}$ ini adalah: pembukuan keuangan dan inventaris (9); membuat laporan neraca keuangan akhir tahun (13); memberdayakan kebiasaan menabung untuk kebutuhan ekonomi yang akan datang (14); dan pola pembagian hasil antar anggota (15). Berdasarkan kondisi di lapang menunjukkan bahwa setiap KUB nelayan masih belum memperhatikan dengan serius tentang pembukuan keuangan kelompok, budaya menabung dan pola pembagian hasil laba KUB nelayan gillnet pada setiap tahun. Kemudian atribut yang termasuk pada aspek lingkungan yang dianggap oleh nelayan tidak terlalu penting dan memiliki tingkat kinerja rendah adalah jenis ikan layak tangkap di perairan (3). Pada aspek kebijakan dalam kuadran ini tidak ada atribut yang tidak terlalu penting atau istimewa. Padahal setiap kuadran C perlu diperhatikan dan dikelola dengan serius.

\section{Kuadran D (Berlebihan)}

Atribut yang terletak pada kuadran ini dianggap sudah memuaskan kinerjanya akan tetapi tidak terlalu penting. Atribut yang ada pada aspek lembaga adalah kriteria dasar pemilihan anggota KUB (1); struktur organisasi dan ketertiban organisasi (3); mentaati semua aturan dalam AD/ART KUB (4); status perkembangan usaha anggota KUB (5); pengembangan kader KUB setiap tahun (6); menyusun, mengajukan, melaksanakan RUB sesuai panduan (10); dan penyuluhan secara berkelanjutan (15). Atribut yang termasuk dalam kuadran ini pada aspek lembaga sudah bagus kinerjanya. Berdasarkan hasil informasi di lapang menunjukkan kinerja atribut struktur organisasi, tata aturan KUB dan pengembangan kader KUB sudah baik.

Atribut pada aspek sosial budaya dalam kuadran ini adalah pola pikir pengembangan usaha (1); partisipasi anggota KUB dalam mengikuti setiap program penyuluhan (3); persepsi anggota terhadap tugas pokok KUB (4); menjadi pengurus dalam KUB (5); menghadiri setiap rapat KUB (8); proses perencanaan, evaluasi dan monitoring kerja secara bersama (13);dan melakukan pencacatan pembukuan setiap kegiatan (20). Atribut yang berada pada kuadran ini sudah berada pada kinerja yang memuaskan sehingga tidak terlalu diprioritaskan lagi. Kemudian atribut yang termasuk pada aspek ekonomi adalah tingkat pemanfaatan modal setiap KUB (1); tingkat persentase menabung dari keuntungan (4); minat tabungan anggota KUB (5); tingkat komitmen dalam penyusunan rancangan keuangan (11); dan pengurus dan anggota KUB melakukan audit keuangan KUB (12).

Jumlah atribut yang dianggap tidak penting oleh KUB nelayan gillnet di Barsela Aceh karena tingkat kinerjanya sudah memuaskan pada aspek lingkungan adalah keadaan lingkungan fishing ground (6); musim penangkapan ikan (7); dan keberlanjutan sumberdaya ikan (8). Adapun atribut pada aspek kebijakan meliputi: aturan tentang pemilihan ketua dan pengurus KUB (3); peraturan dalam mengelola keuangan (7); tata cara simpan pinjam uang oleh anggota KUB (9); dan peraturan tentang pembagian hasil laba antar anggota KUB (11). Atribut ini harus tetap dikelola dan dipertahankan dengan baik karena atribut pada kuadran ini merupakan keunggulan yang dimiliki oleh para KUB nelayan gillnet di Barsela Aceh. Menurut Marini (2014), peningkatan kesejahteraaan masyarakat pesisir (nelayan) diperlukan pengembangan kegiatan bidang ekonomi, pengembangan kualitas sumberdaya manusia dan penguatan kelembagaan sosial ekonomi dengan mendayagunakan sumber perikanan dan kelautan secara optimal dan berkelanjutan.

Menurut Kohar et al. (2011), penilaian kinerja perlu dilakukan untuk mencapai kesejahteraan. Hal ini merupakan terjemahan dari performance yang sering diartikan sebagai penampilan, unjuk rasa, atau prestasi. Para ahli mengemukakan beberapa definisi tentang konsep kinerja. Kinerja adalah gambaran mengenai tingkat pencapaian pelaksanaan suatu kegiatan/program/ kebijakan dalam mewujudkan sasaran. Khususnya tingkat pencapaian kinerja KUB nelayan gillnet di Barsela Aceh.

\section{KESIMPULAN}

Nilai kinerja memiliki kesenjangan pada aspek lembaga $(1,87)$ dan aspek sosial budaya $(1,91)$ adalah kategori cukup baik. Nilai pada aspek ekonomi $(2,12)$, aspek lingkungan $(2,43)$ dan aspek kebijakan $(2,21)$ adalah kategori kurang baik.

Posisi atribut kinerja kuadran A (diproritaskan) meliputi adalah aspek lembaga lima atribut, aspek sosial budaya empat atribut, aspek ekonomi tiga atribut, aspek lingkungan tiga atribut dan aspek kebijakan empat atribut.

\section{SARAN}

Perlu peningkatan dan memperbaiki manajemen kinerja dan sinergi stakeholder 
dalam upaya pengembangan KUB nelayan gillnet di Barsela Aceh dan melakukan penelitian lanjut menilai kinerja terhadap semua jenis usaha alat penangkapan ikan KUB dan jenis KUB berbasis wilayah (kabupaten).

\section{DAFTAR PUSTAKA}

Abdul Kohar $M$, Agus Suherman, Arif Wijayanto. 2011. Performance Analysis of Nusantara Fishery Harbor of Pekalongan. Jurnal Saintek Perikanan. $7(1): 32-38$.

Arifin J. 2007. Cara Cerdas Menilai Kinerja Perusahaan. Jakarta (ID): PT Elex Media Komputindo.

Dowling NA, Dichmont CM, Haddona M, Smitha DC, Smitha DM, Sainsbury K. 2014. Guidelines for Developing Formal Harvest Strategies for DataPoorspecies and Fisheries. Fisheries Research Journal. XXX: 1-11.

Diniah, Sobari MP, Seftian D. 2012. Pelayanan Pelabuhan Perikanan Nusantara (PPN) Terhadap Kebutuhan Operasi Penangkapan Ikan. Jurnal Kebijakan Sosial Ekonomi Kelautan dan Perikanan. 2(1): 41-49

Firdaus M, Apriliani T, dan Wijaya RA. 2013. Pengeluaran Rumah Tangga Nelayan dan Kaitanya dengan Kemiskinan (Kasus Desa Ketampang Barat, Kab.Sampang, Jawa Timur. Jurnal Sosek Kelautan Perikanan. 8(1): 4960.

Firdausi A, Koestiono D, Muhaimin W. 2014. Performance Analysis of Farmer Group and Its Relationship with Household Food Security Level (Case Study In Rasanae Timur Subdistrict Bima City). Jurnal AGRISE . XIV(2): 118-126.

[KKP] Kementrian Kelautan dan Perikanan, 2014. Pedoman Teknis Pelaksanaan Kegiatan Pengembangan Usaha Mina Perdesaan Bidang Perikanan Tangkap. Jakarta: Direktorat Jenderal Perikanan Tangkap No KEP.32/KEP-DJPT/2014Departemen Kelautan dan Perikanan.

Lindawati, Subhechanis Saptanto. 2014. Analisis Tingkat Kemiskinan dan Ketahanan Pangan Berdasarkan Tingkat Pengeluaran Konsumsi pada Rumah Tangga Pembudidaya Ikan (Studi Kasus di Desa Sumur Gintung, Kabupaten Subang, Jawa Barat).
Jurnal. Sosek Kelautan Perikanan. 9(2): 195-206.

Marini IAK, 2014. Analisis Sumber Dan Kesenjangan Pendapatan Rumah Tangga Nelayan Di Wilayah Pesisir Kota Mataram. Gane Ç Swara. 8(2): 16.

Muallil RN, Mamauag SS, Cabral RB, CelesteDizon EO, and Alino PM. 2014. Status, Trends and Challenges in the Sustainability of Small-Scale Fisheries in the Philippines: Insigth from FISHDA (Fishing Industtries Support in Handling Decisions Application) Model. Marine Policy. 44: 212-221.

Nasir H, Rosyid A, Wijayanto D. 2012. Analisis Kinerja Pengelola Pelabuhan Perikanan Nusantara Pekalongan, Jawa Tengah. Journal of Fisheries Resources Utilization Management and Technology. 1(1): 32-45

Nugraha R, Harsono A, Adianto H. 2014. Usulan Peningkatan Kualitas Pelayanan Jasa pada Bengkel " $X$ " Berdasarkan Hasil Matrix ImportancePerformance Analysis (Studi Kasus di Bengkel AHASS PD. Sumber motor kerawang). Jurnal Online Institut Teknologi Nasional Reka Integra. 1(3): 221-231.

Pohandry A, Sidarto, Winarni. 2013. Analisis Tingkat Kepuasan Pelanggan dengan Menggunakan Metode Customer Satisfaction Index dan Importance Performance Analysis Serta Service Quality. Jurnal Rekavasi. 1(1): 21-2

Ramadhani PD, Koestiono D, Maulidah S. 2014. Analisis Tingkat Kepuasan Konsumen Terhadap Kinerja Pelayanan Pemasok Bunga Potong Krisan. Jurnal Habitat. 25(3): 151-161.

Rangkuti F. 2008. Meusuring Customer Satisfaction. Jakarta (ID): PT Gramedia Pustaka Utama.

Roslinawati. 2013. Persepsi Masyarakat Terhadap Program Pemberdayaan Ekonomi Masyarakat Pesisir (PEMP) Di Kabupaten Donggala. Jurnal Academica. 5(2): 1110-1117

Stanford RJ, Wiryawan B, Bengen D, Febriamansyah R, Haluan J. 2014. Enabling and Constraining Factors in the Livelihoods of Poor Fishers in West Sumatra, Indonesia. Journal of International Development. 6(1): 1-10. 
Santoso. 2011. Persepsi Konsumen Terhadap Kualitas Bakpao Telo Dengan Metode Importance Performance Analysis (IPA). Jurnal Teknologi Pertanian.12(1): 9- 21
Sukardi, Chodilis Chandrawatisma. 2009. The Analysis of Customer Satisfaction Of Corned Pronas Product of PT Cip, Denpasar, Bali. Jurnal Teknik Industri Pertanian. 18(2): 106-117 